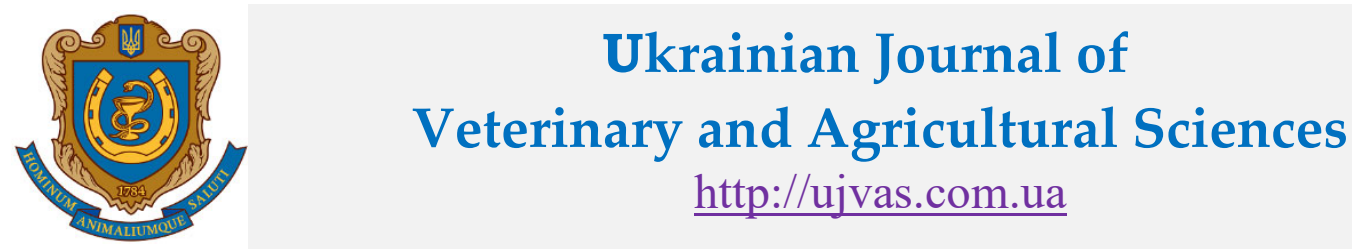

Stepan Gzhytskyi National University of Veterinary Medicine and Biotechnologies Lviv original article $\mid$ UDC 639.2.052.2/3 $\mid$ doi: 10.32718/ujvas2-3.06 $\quad$ Number 3

\title{
The current state of fishing and extracting the living aquatic resources in the Black Sea region of Ukraine
}

\author{
M. I. Burgaz, T. I. Matviienko, O. M. Soborova, K. I. Bezyk, O. Y. Kudelina \\ Odessa State Ecological University, Lvivska Str., 15, Odessa, 65016, Ukraine
}

\begin{tabular}{l} 
Article info \\
Received 04.11.2019 \\
Received in revised form \\
05.12 .2019 \\
Accepted 06.12.2019 \\
\hline Correspondence author \\
Marina Burgaz \\
Tel.: +38-067-990-49-26 \\
E-mail: marinaburgaz14@gmail.com \\
\hline
\end{tabular}

2019 Burgaz M. et al. This is an open-access article distributed under the terms of the Creative Commons Attribution License, which permits unrestricted use, distribution, and reproduction in any medium, provided the original author and source are credited.

\section{(cc) $\mathrm{BY}$}

Contents

1. Introduction

2. Materials and methods ...... 24

3. Results and discussion ...... 24

4. Conclusions .............. 27

References .................... 27

\begin{abstract}
The development of open spaces and resources of the Black Sea is one of the main directions of the Black Sea region (the Odessa, Mykolaiv and Kherson regions). The essence of the region policy allows to cooperate with the most countries of the world community and brings an income both to the budget of the regions and to the state budget. Industrial fisheries is an extractive branch of the fishing industry that uses the natural resources of the oceans, seas, lakes, rivers, reservoirs: various species of fish, marine mammals, shellfish, crustaceans and aquatic vegetation. Fisheries can be considered as one type of nature using which consists in the extraction of fish and other sea products (fish, invertebrates, algae, etc.). The purpose of the work was to find out a current state of fishing and extracting the living aquatic resources in the Black Sea region, namely in the Odessa, Mykolaiv and Kherson regions. An assessment of a current state of extracting the aquatic bioresources in general and in the inland water bodies in the Black Sea region, namely in the Odessa, Mykolaiv and Kherson regions for the period from 2010 to 2018, was carried out on the basis of specialized literature. The state of extracting the aquatic bioresources in general and in the inland water bodies from 2010 to 2018; the amount of caught fish in this region; the state of fisheries of the studied region were investigated. Fish farming is a branch of the national economy that is engaged in farming, increasing and improving a quality of the fish stocks in the water bodies and filling the fish resources. In order to maintain and increase the stocks of valuable industrial fish in our country the extensive measures for artificial fish farming, improving the conditions of natural reproduction of fish, as well as the development of lake and pond fisheries for the commercial fish production are being taken. Much work is being done to acclimatize valuable industrial fish species and other fishing objects, aimed at expanding a fish species composition and increasing the fish stocks. It was found that according to the statistics of the State Statistics Committee of Ukraine, the analysis of the exraction of fish and aquatic biological resources in the Black Sea region (Odesa, Mykolaiv and Kherson regions) showed that an increase in the volume of fish catching and extracting the living aquatic resources occurred only due to inland waters.
\end{abstract}

Key words: fisheries, fish, seafood, catch volumes, extraction, aquatic bioresources, production, fishing.

\section{Citation:}

Burgaz, M. I., Matviienko, T. I., Soborova, O. M., Bezyk, K. I., \& Kudelina, O. Y. (2019). The current state of fishing and extracting the living aquatic resources in the Black Sea region of Ukraine. Ukrainian Journal of Veterinary and Agricultural Sciences, 2(3), 23-27.

\section{Introduction}

The development of open spaces and resources of the Black Sea is one of the main directions of the Black Sea region (the Odessa, Mykolaiv and Kherson regions). The essence of the region policy allows to cooperate with the most countries of the world community and brings an income both to the budget of the regions and to the state budget (Kolesnikova, 2011).

Nowdays the rapid increase of the modern fleet, the development of the improved fishing techniques, the processing of catches and the preservation of the production have led to a significant consumption of the biological resources of the Black Sea. The Black Sea biological resources are exhaustive, although they are renewing they require proper management of fisheries.
At the present stage of the development the fishing industry is an important component of Ukrainian economy. The development and the implementation of the innovative technologies in fisheries and fish processing require a mandatory and ongoing analysis of the fish market infrastructure. The need of the population for food protein which is characterized by a balanced amino acids composition is provided by fish and seafood by 20-30 \% (Demchuk \& Dracheva, 2013; Pivtorak \& Bobel, 2017; Bobel et al., 2018).

The purpose of the work was to find out a current state of fishing and extracting the living aquatic resources in the Black Sea region, namely in the Odessa, Mykolaiv and Kherson regions.

To achieve this goal the following tasks were set:

1. to analyze a state of extracting the aquatic bioresources in general and in the inland water bodies; 
2. to determine the amount of fish caught in this area;

3 . to analyze a current state of fishing of the studied region.

\section{Materials and methods}

On the basis of specialized literature, an assessment of a current state of the extraction of aquatic bioresources in general and in the inland water bodies in the Black Sea region, namely in the Odessa, Mykolaiv and Kherson regions for the period from 2010 to 2018 was carried out.

\section{Results and discussion}

Industrial fisheries is an extractive branch of the fishing industry that uses the natural resources of the oceans, seas, lakes, rivers, reservoirs: various species of fish, marine mammals, shellfish, crustaceans and aquatic vegetation. Fisheries can be considered as one type of nature using which consists in the extraction of fish and other sea products (fish, invertebrates, algae, etc.). There are industrial, amateur and sport fishing (Kolesnikova, 2011).

Fish and fish products are a very important element of a balanced diet, a source of about 1/4 of animal protein. It is not surprisingly that $72-75 \%$ of the world catch is intended for human nutrition, the rest is processed into fish meal, nutritional supplements, fish oil and is used for livestock feeding or in pharmaceuticals.
Fisheries is of major social (especially in the coastal areas, where up to $70 \%$ of the industry's production potential is concentrated) and geopolitical importance to the country.

The Odessa, Mykolaiv and Kherson regions are characterized a current state of fishing and extracting in the Black Sea region.

The Odessa region with an area of 33.3 thousand $\mathrm{km}^{2}$ (5.5\% of the area of Ukraine) is located within the basins of the rivers Danube, Dniester, Southern Bug, and the rivers of the Black Sea.

There are about 1140 rivers with the inflows of all orders, more than 270 water bodies of local importance $(8$ reservoirs, ponds and lakes) and more than 790 water bodies of national importance (26 estuaries, 50 reservoirs, ponds and lakes) in the region (Derzhavna sluzhba statystyky Ukrainy).

The Odessa region has many ponds whose main purpose is fish farming. Most of the ponds are in the territory of the Lyubashivsky (100 pcs.) and Baltic (97 pcs.) districts.

Nowdays the Odessa, Mykolaiv and Kherson regions are among the most important and promising fisheries regions of Ukraine.

According to the State Statistics Committee of Ukraine (Table 1) during the period from 2010 to 2018 in the Odessa region there is a steady decrease in fish catching but the extraction of aquatic bioresources in the inland water bodies is increasing every year.

\section{Table 1}

Fishing and extracting the aquatic bioresources of the Odessa region from 2010 to 2018 (according to the State Statistics Committee of Ukraine (Dobuvannia vodnykh bioresursiv za rehionamy))

\begin{tabular}{|c|c|c|c|c|c|c|}
\hline \multirow{3}{*}{ Years } & \multicolumn{4}{|c|}{ The extraction of aquatic bioresources } & \multirow{2}{*}{\multicolumn{2}{|c|}{ Including fish }} \\
\hline & \multicolumn{2}{|r|}{ total } & \multicolumn{2}{|c|}{ including the inland water bodies } & & \\
\hline & $\mathrm{T}$ & $\begin{array}{c}\% \text { before } \\
\text { the previous year }\end{array}$ & tons & $\begin{array}{c}\% \text { before } \\
\text { the previous year }\end{array}$ & tons & $\begin{array}{c}\% \text { before } \\
\text { the previous year }\end{array}$ \\
\hline 2010 & 19527 & 39.9 & 4344 & 75.8 & 19073 & 39.5 \\
\hline 2011 & 10150 & 52 & 5510 & 126.8 & 9847 & 51.6 \\
\hline 2012 & 10318 & 101.7 & 5351 & 97.1 & 9542 & 96.9 \\
\hline 2013 & 9700 & 94 & 5462 & 102.1 & 8904 & 93.3 \\
\hline 2014 & 8894 & 91.7 & 5552 & 101.6 & 8258 & 92.7 \\
\hline 2015 & 22245 & 250.1 & 5077 & 91.5 & 8499 & 102.9 \\
\hline 2016 & 17500 & 78.7 & 8587 & 101 & 6186 & 121.8 \\
\hline 2017 & 10933 & 62.5 & 9216 & 107.3 & 6644 & 107.4 \\
\hline 2018 & 12803 & 117.1 & $\mathrm{k}$ & $\mathrm{k}$ & 7963.7 & 86.4 \\
\hline
\end{tabular}

Symbol (k) means that the data are not disclosed to ensure compliance with the requirements of the Law of Ukraine "On the State Statistics" which relate to confidentiality.

Thus in 2010 the extraction of aquatic bioresources in the internal objects of the Odessa region amounted to 4344 tons, and in 2017 it doubled and amounted to 9216 tons (Fig. 1). A significant increase in the extraction of aquatic bioresources in the inland facilities has been observed since 2015, which may be related to the rapid development of fisheries. The data for 2018 are not disclosed to ensure compliance with the requirements of the Law of Ukraine "On the State Statistics" which relate to confidentiality.

In 2010 the fish catch in the Odessa region was 19073 tonnes, and in 2018 it decreased almost three times and amounted to 7963.7 tonnes (Fig. 2).

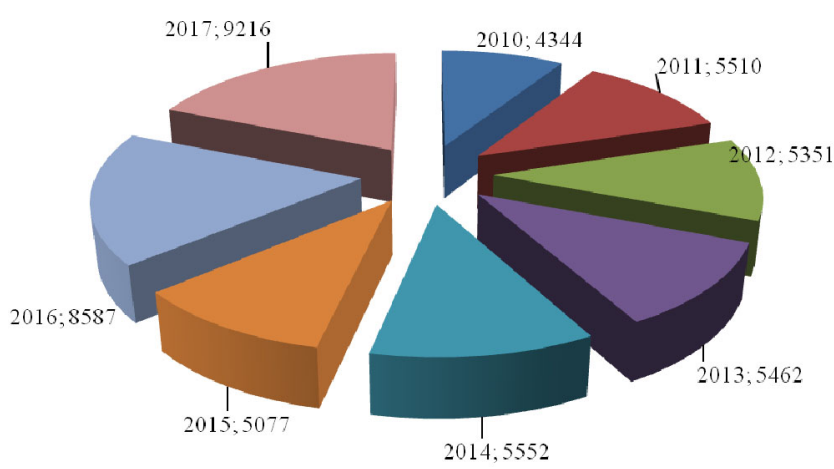

Fig. 1. Catching the aquatic bioresources in the inland water bodies of the Odessa region. (according to the State Statistics Committee of Ukraine) 


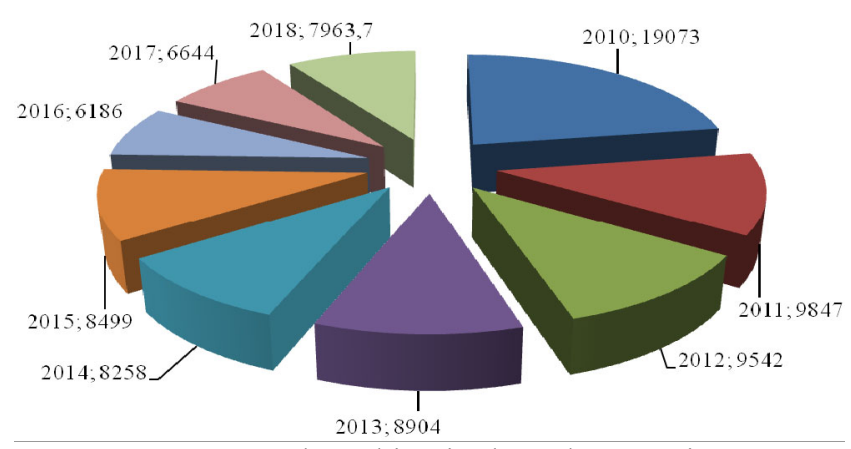

Fig. 2. Total catching in the Odessa region.

(according to the State Statistics Committee of Ukraine)

(Dobuvannia vodnykh bioresursiv za rehionamy)

The following factors influenced on the critical state of the industry both in the Odesa region and in the country as a whole: an annexation of the Autonomous Republic of the Crimea, an unstable political and economic situation in the country, reorientation of budgetary financial resources to other sectors of the national economy but not to the fishing industry; etc.

The Mykolayiv region is another of the main areas in the Black Sea region important for fisheries of Ukrainian.
The Mykolaiv region covers an area of 24.6 thousand $\mathrm{km}^{2}$, which is $4.07 \%$ of the total area of Ukraine. The territory of the region has 121 rivers and beams, one large river is the Southern Bug and six middle rivers are the Kodyma, Sinyukha, Black Tashlyk, Chichikleya, Ingul, Ingulets, Vysun (Vodni resursy).

There are counted 26 lakes, 45 built reservoirs and 1153 built ponds in the region and $90 \%$ of them are located on the small rivers. The length of the Black Sea coastline in the Mykolaiv region is $59.3 \mathrm{~km}$, including the length from the border of the Odessa and Mykolaiv region to the Berezansky estuary $(6.0 \mathrm{~km})$ and from the Berezansky estuary to Ochakov $(27.5 \mathrm{~km})$; along the Kinbour Peninsula $(22.7 \mathrm{~km})$, Berezan Island $(2.0 \mathrm{~km})$; Krugly Island $(0.7 \mathrm{~km})$; Long Island $(7.4 \mathrm{~km})$. The length of the Yagorlytsky tributary coastline in the Mykolaiv region is $21.9 \mathrm{~km}$. On the territory of the Mykolaiv region, the Berezansky, Beyuksky, Buzky, Karabushsky, Sositsky estuaries are counted and on the border with the Odessa region the Tiligulsky estuary is (Vodni resursy).

According to the State Statistics Committee of Ukraine (Table 2), during the period from 2010 to 2018 there is a tendency to reduce catching fish and extracting the aquatic bioresources in the inland water bodies in the Mykolayiv region.

Table 2

Catching fish and extracting the aquatic bioresources of the Mykolaiv region during the period from 2010 to 2018 (according to the State Statistics Committee of Ukraine (Dobuvannia vodnykh bioresursiv za rehionamy))

\begin{tabular}{|c|c|c|c|c|c|c|}
\hline \multirow{3}{*}{ Years } & \multicolumn{4}{|c|}{ The extraction of aquatic bioresources } & \multirow{2}{*}{\multicolumn{2}{|c|}{ Including fish }} \\
\hline & \multicolumn{2}{|r|}{ total } & \multicolumn{2}{|c|}{ including the inland water bodies } & & \\
\hline & $\mathrm{T}$ & $\begin{array}{c}\% \text { before } \\
\text { the previous year }\end{array}$ & tons & $\begin{array}{c}\text { in } \% \text { to } \\
\text { the previous year }\end{array}$ & tons & $\begin{array}{c}\% \text { before } \\
\text { the previous year }\end{array}$ \\
\hline 2010 & 3000 & 76.0 & 2483 & 79.3 & 2992 & 76.3 \\
\hline 2011 & 3753 & 125.0 & 2578 & 103.8 & 3746 & 125.1 \\
\hline 2012 & 2883 & 76.8 & 2745 & 106.5 & 2874 & 76.7 \\
\hline 2013 & 3294 & 114.3 & 2999 & 109.3 & 3283 & 114.3 \\
\hline 2014 & 12644 & 383.8 & 1964 & 65.5 & $\mathrm{k}$ & $\mathrm{k}$ \\
\hline 2015 & 1934 & 15.3 & 1708 & 87.0 & 1910 & 55.6 \\
\hline 2016 & 1856 & 96.0 & 1793 & 93.9 & 1502 & 88.0 \\
\hline 2017 & 10572 & 569.5 & 2541 & 141.7 & 2227 & 148.2 \\
\hline 2018 & 18777.6 & 177.6 & $\mathrm{k}$ & $\mathrm{k}$ & $\mathrm{k}$ & $\mathrm{k}$ \\
\hline
\end{tabular}

Symbol (k) means that the data are not disclosed to ensure compliance with the requirements of the Law of Ukraine "On the State Statistics" which relate to confidentiality.

Thus in 2010 the extraction of aquatic bioresources in the internal objects of the Mykolaiv region was 2483 tons, and in 2017 the extraction remained almost at the same place and amounted to 2541 tons (Fig. 3).

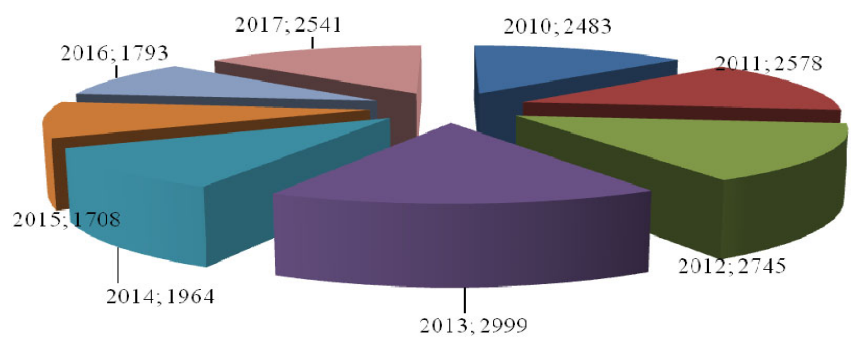

Fig. 3. Catching the aquatic bioresources in the inland water bodies of the Mykolaiv region.

(according to the State Statistics Committee of Ukraine) (Dobuvannia vodnykh bioresursiv za rehionamy)
The decline in the extraction of aquatic bioresources in the inland objects is observed in 2014, which may be due to an unstable political and economic situation in the country. The data for 2018 are not disclosed to ensure compliance with the requirements of the Law of Ukraine "On the State Statistics" which relate to confidentiality.

In 2010 the fish catch in the Mykolaiv region was 2992 tons, and in 2017 it decreased and amounted to 2227 tons (Fig. 4).

Since 2014 there has been a decline in fish catching, but in recent years fishing has returned to its place, and the catches are gradually increasing.

The Kherson region is also one of the most important regions of Ukraine for the extraction of fish and aquatic bioresources.

The Kherson region is located in the south of Ukraine, in the basin of the lower Dnieper, within the Black Sea lowland. In the south the Kherson region is washed by the Black 
and Azov seas as well as the Sivash (The Rotten Sea). The water bodies of the Kherson region occupy 430.5 thousand hectares (Zabezpechenist oblasti vodnymy resursamy).

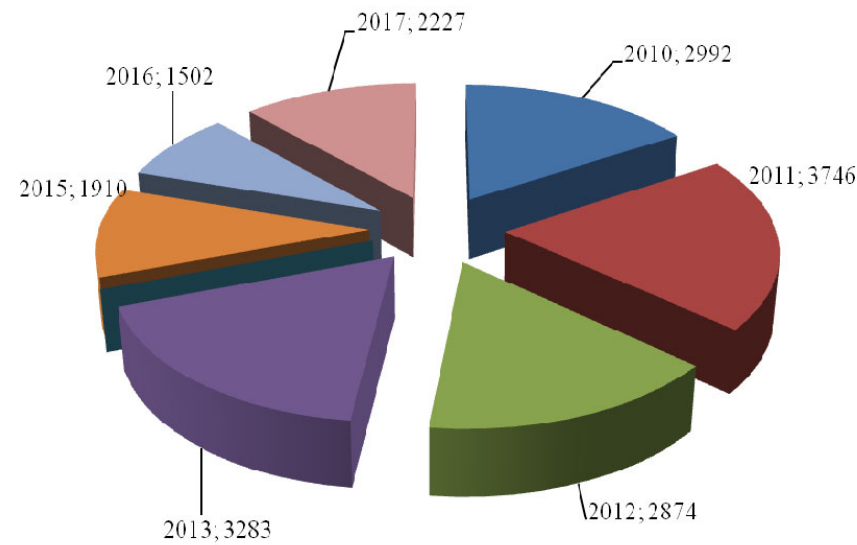

Fig. 4. Total fishing in the Mykolaiv region. (according to the State Statistics Committee of Ukraine) (Dobuvannia vodnykh bioresursiv za rehionamy)
Natural streams cover an area of 10.67 thousand hectares. 26 rivers flow through the region, including the Dnieper River ( $200 \mathrm{~km}$ in length within the region) with the Kakhovka Reservoir, the Ingulets River $(180 \mathrm{~km})$ and 24 rivers with a total length of $373.7 . \mathrm{km}$. There are 693 lakes in the region with a total area of 170.22 thousand hectares and 1154 ponds with an area of 12.3 thousand hectares. Artificial reservoirs occupy 64.28 thousand hectares (Zabezpechenist oblasti vodnymy resursamy).

According to the State Statistics Committee of Ukraine (Table 2) during the period from 2010 to 2018 in the Kherson region there is a tendency toward an increase in fish catching and extracting the aquatic bioresources in the inland water bodies, but the exraction of fish remains stable.

In 2010 the extraction of aquatic bioresources in the inland waterb objects of the Kherson region amounted to 1717 tonnes, and since 2016 there has been an increase in extracting and in 2017 the extraction was 7208 tons, which is seven times more than the 2010 extraction. (Fig. 5).

\section{Table 3}

Catching the fish and extracting the aquatic bioresources of the Kherson region from 2010 to 2018 (according to the State Statistics Committee of Ukraine (Dobuvannia vodnykh bioresursiv za rehionamy))

\begin{tabular}{|c|c|c|c|c|c|c|}
\hline \multirow{3}{*}{ Years } & \multicolumn{4}{|c|}{ The extraction of aquatic bioresources } & \multirow{2}{*}{\multicolumn{2}{|c|}{ Including fish }} \\
\hline & \multicolumn{2}{|r|}{ total } & \multicolumn{2}{|c|}{ including the inland water bodies } & & \\
\hline & tons & $\begin{array}{c}\% \text { before } \\
\text { the previous year }\end{array}$ & tons & $\begin{array}{c}\% \text { before } \\
\text { the previous year }\end{array}$ & tons & $\begin{array}{c}\% \text { before } \\
\text { the previous year }\end{array}$ \\
\hline 2010 & 4801 & 88,9 & 1717 & 74,4 & 4681 & 87,8 \\
\hline 2011 & 5940 & 123,7 & 1853 & 108,0 & 5805 & 124,0 \\
\hline 2012 & 5848 & 98,4 & 2476 & 133,5 & 5795 & 99,8 \\
\hline 2013 & 4036 & 69,0 & 2879 & 116,3 & 3922 & 67,7 \\
\hline 2014 & 2832 & 70,2 & 2345 & 81,5 & 2707 & 69,0 \\
\hline 2015 & 4530 & 159,9 & 2461 & 105,0 & 4141 & 153,0 \\
\hline 2016 & 7095 & 156,6 & 6552 & 158,2 & 2673 & 108,6 \\
\hline 2017 & 7517 & 105,9 & 7208 & 110,0 & 2466 & 92,2 \\
\hline 2018 & 5589,8 & 74,4 & $\mathrm{k}$ & $\mathrm{k}$ & 5456,4 & 75,7 \\
\hline
\end{tabular}

Symbol (k) means that the data are not disclosed to ensure compliance with the requirements of the Law of Ukraine "On the State Statistics" which relate to confidentiality.

A significant increase in the extraction of aquatic bioresources is associated with an increase in the industrial development in the region. Data for 2018 are not disclosed to ensure compliance with the requirements of the Law of Ukraine "On the State Statistics" which relate to confidentiality.
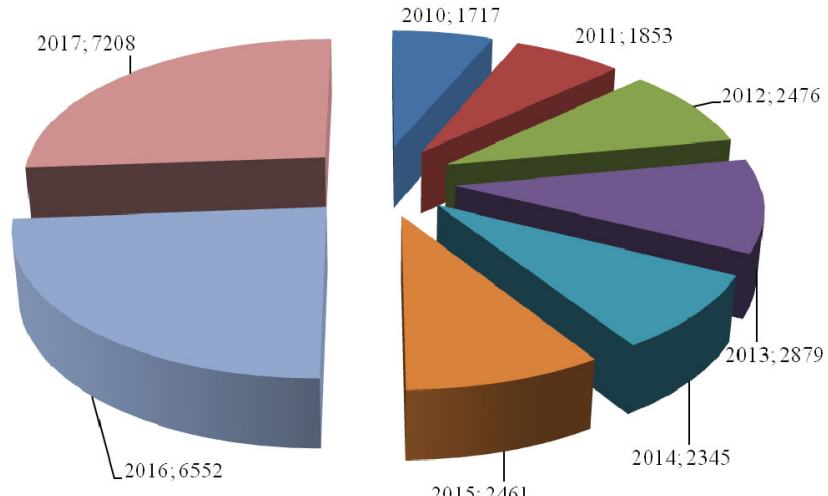

Fig. 5. Catching the aquatic bioresources in the inland water bodies of the Kherson region.

(according to the State Statistics Committee of Ukraine) (Dobuvannia vodnykh bioresursiv za rehionamy)

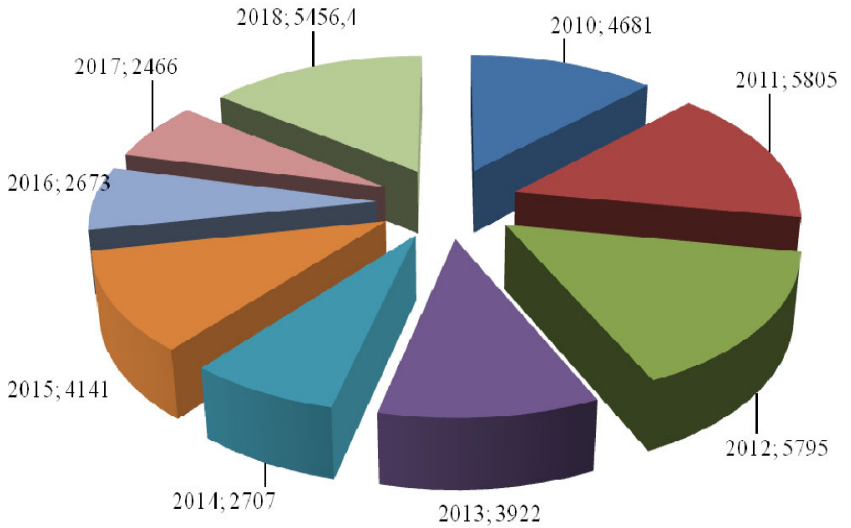

Fig. 6. Total fish catching in the Kherson region. (according to the State Statistics Committee of Ukraine)

(Dobuvannia vodnykh bioresursiv za rehionamy)

In 2010 the catch of fish in the Kherson region amounted to 4.681 tonnes, and in 2014 the decline in the extraction to 2707 tonnes was observed, but in 2017 the extraction again doubled and amounted to 5456.4 tonnes (Fig. 6). 
Thus, having examined the statistics on extracting the fish and aquatic bioresources for the period from 2010 to 2018 , it can be noted that in each of the studied areas (Odesa, Mykolaiv and Kherson), there is an increase in extracting and the extraction has increased most in the inland waters of the region.

\section{Conclusions}

Fish farming is a branch of a national economy that is engaged in farming, increasing and improving a quality of the fish stocks in the water bodies and filling the fish resources. In order to maintain and increase the stocks of valuable industrial fish in our country the extensive measures for artificial fish farming, improving the conditions of natural reproduction of fish, as well as the development of lake and pond fisheries for the commercial fish production are being taken. Much work is being done to acclimatize valuable industrial fish species and other fishing objects, aimed at expanding a fish species composition and increasing the fish stocks.

The industrial catch of fish and aquatic bioresources in Ukraine is increasing every year, and most of all it happens in the Black Sea region (the Odessa, Mykolaiv and Kherson regions).

Analysis of the statistical data on extracting fish and aquatic bioresources in the Black Sea region (the Odesa, Mykolaiv and Kherson regions) showed that the increase in fish catching and extracting the living aquatic resources is only due to the inland water bodies.

The analysis of the situation over the last 10 years in this area shows that the needs of the population of the Black Sea region are being met mainly by increasing the catch in the inland water bodies and the imports, as well as increasing the illegal market sales. Thus, legal fishing and seafood extracting have been steadily declining in recent years, while the supplies of imported fish products on the contrary have increased.
Despite the currently observed negative economic and ecological phenomena in the country, an analysis of the perspectives for the development of a fishery complex in Ukraine gives reason to hope that its fishery activity will be resumed at the level sufficient to meet the nutritional needs of the population in fish and fish products, which can only be achieved if the strategic directions for the development of the industry both at the state level and in the regions are correctly identified.

\section{References}

Bobel, I., Pivtorak, J., \& Petryshak, R. (2018). Economic efficiency of growing commodity trout in farms in the Western Ukraine while feeding with forages Aller Aqua. Scientific Messenger of LNU of Veterinary Medicine and Biotechnologies. Series: Agricultural Sciences, 20(89), 71-74. doi: $10.32718 /$ nvlvet 8913 .

Demchuk, O. V., \& Dracheva, M. V. (2013). Sovremennoe sostoyanie ry 'bnoj otryasli i perspektivy` razvitiya ry`nka ry 'bnoj produkczii v Ukraine. Ribne gospodarstvo Ukrayiny, 5/13, 4751. http://nbuv.gov.ua/UJRN/rgu 2013510 (in Russian).

Derzhavna sluzhba statystyky Ukrainy [Elektronnyi resurs] Rezhym dostupu: http://www.ukrstat.gov.ua (in Ukrainian).

Dobuvannia vodnykh bioresursiv za rehionamy [Elektronnyi resurs] Rezhym dostupu: http://www.ukrstat.gov.ua/operativ/ operativ2017/rg/rg_u/rg_reg0417_u.htm (in Ukrainian).

Kolesnikova, E. S. (2011). Prichernomorskij regi'on: Problemy', anali z i razvitie. Problemy 'material 'noj kul tury', 212, 39-43. http://dspace.nbuv.gov.ua/handle/123456789/64685 (in Russian).

Pivtorak, J. I., \& Bobel, I. Y. (2017). Intensity of growth and development of rainbow trout using feeds Aller Aqua and Aquafeed Fischfutter. Scientific Messenger LNUVMB, 19(79), 7377. doi: 10.15421/nvlvet7915.

Vodni resursy [Elektronnyi resurs] Rezhym dostupu: http://mkvodres.davr.gov.ua/water_resources (in Ukrainian).

Zabezpechenist oblasti vodnymy resursamy [Elektronnyi resurs] Rezhym dostupu: http://buvr.kherson.ua/vodnye_resursy.htm (in Ukrainian) 